\title{
Assessing Food Hygiene Knowledge and Practice of On- Campus Food Handler During Pandemic COVID-19
}

Nur Afif Nabilah Abu Bakar, Norhidayah Abdullah, Norhayati Mat Yusoff @ Mohd Yusof, Noriza Ishak

To Link this Article: http://dx.doi.org/10.6007/IJARBSS/v10-i12/8617 DOI:10.6007/IJARBSS/v10-i12/8617

Received: 05 November 2020, Revised: 07 December 2020, Accepted: 16 December 2020

Published Online: 01 January 2021

In-Text Citation: (Abu Bakar et al., 2020)

To Cite this Article: Abu Bakar, N. A. N., Abdullah, N., Yusof, N. M. Y.@ M., \& Ishak, N. (2020). Assessing Food Hygiene Knowledge and Practice of On-Campus Food Handler During Pandemic COVID-19. International Journal of Academic Research in Business and Social Sciences, 10(12), 1305-1316.

\section{Copyright: @ 2020 The Author(s)}

Published by Human Resource Management Academic Research Society (www.hrmars.com) This article is published under the Creative Commons Attribution (CC BY 4.0) license. Anyone may reproduce, distribute, translate and create derivative works of this article (for both commercial and non-commercial purposes), subject to full attribution to the original publication and authors. The full terms of this license may be seen at: http://creativecommons.org/licences/by/4.0/legalcode

Vol. 10, No. 12, 2020, Pg. 1305 - 1316 


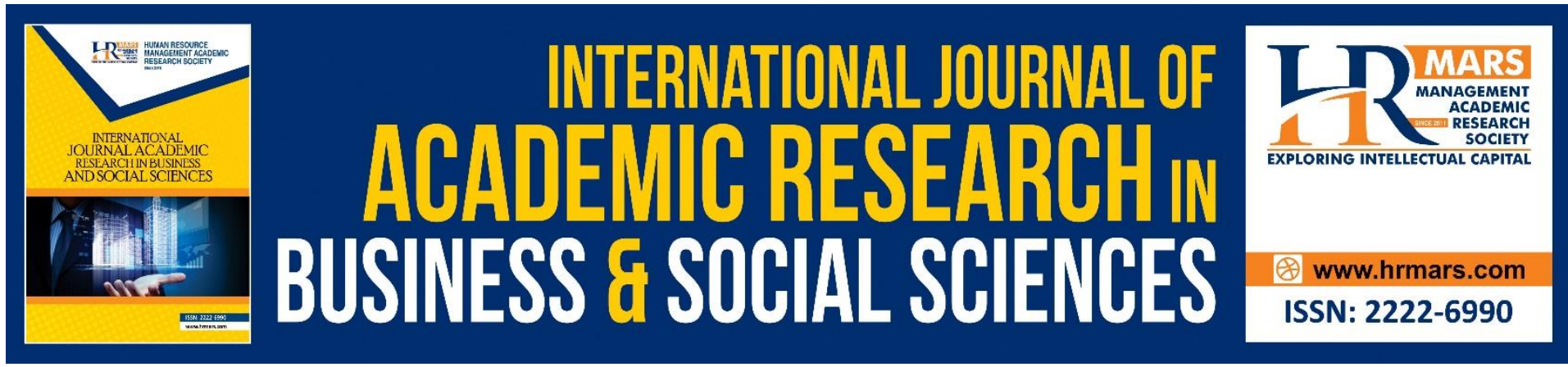

\title{
Assessing Food Hygiene Knowledge and Practice of On-Campus Food Handler During Pandemic COVID-19
}

\author{
Nur Afif Nabilah Abu Bakar, Norhidayah Abdullah, Norhayati Mat \\ Yusoff @ Mohd Yusof, Noriza Ishak
}

Faculty of Hotel and Tourism Management, Universiti Teknologi MARA Selangor, Puncak Alam Campus, Selangor, Malaysia

\begin{abstract}
Foodservice outlet in universities is the main dining platform for students and it creates a high dependency on the food sold in campus. However, episodes of food poisoning in Malaysia are still occurring in universities and colleges due to improper practices among food handlers. The concern arises when the students are exposed to the risk of foodborne illness. Therefore, this study aims to assess the relationship between knowledge, attitude, and practice of food safety and hygiene among food handlers at foodservice outlets in five campuses in Selangor. A crosssectional study was conducted among 90 food handlers who met the criteria set in this study. The data gathered were analysed using SPSS software version 24. Food handlers shown good knowledge towards food hygiene but slightly poor in association to time and temperature control as well as cross contamination while even though shown good attitude and hygiene practice. Weak and positive correlations were observed for knowledge and practice, and knowledge and attitude whereby attitude and practice resulted in moderate positive correlation. Further analysis through linear regression proved that attitude mediated the relationship between knowledge and practice on food safety and hygiene. The finding of this study may help in monitoring and improving the knowledge, attitude, and practice of food safety and hygiene among food handlers. Thus, it reduces the risk of food contamination and foodborne diseases.
\end{abstract}

Keywords: Attitude, Food Handler, Food Hygiene Knowledge, On Campus, Practice.

\section{Introduction}

According to the Department of Statistics Malaysia (2017), the performance of food and beverage services has increased as the census result showed that the recent number of food and beverage service establishments operated have also increased to 167,490 as compared to 2010 which was 130,570. However, all countries including Malaysia's social life and economic sector were paralysed due to the pandemic disease of COVID-19 which first emerged in Wuhan City, China at the end of December 2019 (Duda-Chodak et al., 2020). Currently, there is no evident that Covid-19 can spread through food but its primary transmission mode was through droplets either coughing, sneezing, or even talking or communicating, and close contact with 
the infected person (Elengoe, 2020). Therefore, proper practices such as wearing face shield or face mask and glove can reduce the risk of virus transmission during the deal between food handlers and customers. All types of food and beverages sold were handled by food handlers either direct or indirect contact with the food and customers. The improper handling of food could result in food contamination and cause foodborne illnesses among the consumers. Similar to the disease stated above, the virus can rapidly spread if the food handler and customer do not follow the Standard Operating Procedure (SOP) set by the Malaysian government as to wear mask properly, clean and sanitize hands regularly, and practice social distancing. Lee, Halim, Thong and Chai (2017) stated that improper food handling practices by food handlers have contributed to more than half of the total cases of food poisoning that occurred in this country. Therefore, food safety and hygiene practices among food handlers have become a major concern in foodservice organization as they can act as a carrier for transmission of harmful bacteria and virus towards food and humans (Kubde, Pattankar, \& Kokiwar, 2016).

In addition, Covid-19 pandemic crisis has also affected food stock and food accessibility as consumers tend to do 'panic buying' as they feel worried if no food is left when being at home in certain area that undergoes 'lockdown'. The issue arises when excessive raw meat and others were bought and not stored properly. In the end, the quality of the food drops and increases the tendency of foodborne illness or turns to wastage. Even though this disease has continued to hit the countries around the world, food industry has introduced innovative products such as 'Lemang' instant from Nona's brand to fulfil the demand of Eid Fitri festival food celebrated by Muslims during the movement control order (PKP) in Malaysia. According to Liyana (2020), the Ministry of Health Malaysia has verified that cook 'Lemang' in recycled tins is not safe as it contains chemical substances that can react to food when exposed to heat and can cause chemical contamination. This shows that food handling is particularly important to ensure safe food is consumed.

\section{Literature Review}

Academic institutions' food premises have increased due to the demand on the emergence of students from higher academic institutions. In Malaysia's higher education institutions of the public sector, there are 20 universities, 34 polytechnics, and 94 community colleges (Yahaya, 2018). From only cafeteria and food court being present in the university, small kiosks have been widely introduced to increase food varieties and choices. Furthermore, as one of the initiatives to encourage students to run business and instil or nurture entrepreneurial skills, special kiosks have also been prepared. In universities especially college residences, the students highly depend on the food sold in the university

to satisfy their hunger. High dependency on food served in the campus requires safe food practices among food handlers that need to be monitored regularly to avoid food contamination from occurring. Plus, during this pandemic disease, the issue of staffing has arisen when physical or social distancing were set as preventative measures to lower the risk of Covid-19 spread. Small kitchen areas such as kiosk and café lots may need only one or 2 persons while the rest might be put off or take turn in another shift to comply with the SOP and reduce close contact. The foodservice business in the institution has also dropped due to the limited campus operations. 
Furthermore, the state of Selangor has contributed the highest cases of food poisoning in Malaysia. As mentioned by Lee et al. (2017), from the total episodes of food poisoning that happened in Malaysia, about 43\% of them were contributed by outbreaks in academic institutions due to improper food hygiene practices among food handlers. Student complaint on having food poisoning after consuming food bought from on campus food premises (Jurnalis Shah Alam, 2019). It can be seen that the issue of foodborne illness in the university is still happening even until today. In fact, there were also some incidences where the issue was not reported by the victims due to complicated procedures of bringing up the cases to the authority (Soon, Singh \& Baines, 2011). Therefore, the exact data were underestimated as not all the victims obtained treatment at the medical centre and made a report of their situations. The series of serious cases may affect the student's academic focus and achievement as well as negative perception towards the university's performance.

\section{Methodology \\ Material \& Methods}

A quantitative research approach was undertaken in which this method focused on statistical analysis of numerical data collected using a structured self-administered questionnaire. Besides, as the objective of the study was to determine the relation between knowledge, attitude, and practice of food safety and hygiene among food handlers, a correlational research design was chosen. This research design involved a cross-sectional study in which the data were gathered at once only. In addition, this study involved food handlers in any on campus foodservice outlets in Selangor. Therefore, any food handler who is working at any 5 campuses in Selangor with the handling of any aspect of food preparation, storage, and serving on the site of premises would be the criteria for being chosen as a respondent. The questionnaire used in this study was adapted from previous published research (Dora-Liyana, Mahyudin, IsmailFitry, Ahmad-Zaki, \& Rasiyuddin, 2018; Nur Izyan et al., 2019; Akabanda, Hlortsi, \& OwusuKwarteng, 2017; Al-Kandari, Al-Abdeen, \& Sidhu, 2019). Some of the items in the questionnaire were modified from question form to general true statements. Then, with the consent from the respective respondents, the data from 90 food handlers were successfully gathered through a simple random sampling technique.

The survey instrument which is the questionnaire of this study consisted of four sections starting from demographic profile of the respondents, followed by food safety knowledge, food safety attitude and food safety practice. A four-point Likert scale ranging from 1 to 4 which represented 'Strongly Disagree', 'Disagree', 'Agree', and 'Strongly Agree' was used for all items measuring knowledge, attitude, and practice to avoid 'neutral' answer. Also, the use of 4 points of Likert Scale was to reach an optimum measure when neutral point, number of options to rate, and reliability were being considered (Borgers, Sikkel, \& Hox, 2004). Furthermore, as all the questions were true statements, one point was awarded for those who answered 'strongly agree' and 'agree' whereby zero point was given to 'disagree' and 'strongly disagree' option.

\section{Result and Analysis Demographic Profile}

Majority of the respondents were from a local higher institution in Selangor branch as there was a higher number of foodservice outlets available in this branch campus. The total number of male respondents was 48 with $53 \%$ while female respondents were 42 with $46.7 \%$. Besides, majority of the respondents were between 21 to 30 years old and had at least secondary school 
as their highest education background. Majority had one to three years of working experience in foodservice. However, with that range of working experience in foodservice, $71.1 \%(n=64)$ of the samples were full time workers while the rest were part time workers with $28.9 \%(n=26)$. Next, the respondents from the cafeteria represented the most with $55.6 \%(n=50)$ as compared to kiosks or stalls which contributed $23.3 \%(n=21)$.

\section{Food Safety Knowledge Among on Campus Food Handler}

In general, the percentage score for the agree response was from $70 \%$ to $96.7 \%$ whereby the disagree response was from $3.3 \%$ to $30.0 \%$. Most of the respondents agreed $(96.7 \%)$ on the statement that it is necessary to wash hands before and after using gloves. This showed the food handlers knew that washing the hands can keep them clean before and after wearing gloves prior to preparing food. Only a few (3.3\%) disagreed on this knowledge statement. Proper hand washing can be one of the adequate measures to diminish the transmission of microbes towards food prepared and cross contamination prevention. Moreover, microbes such as Staphylococcus bacterium were easily transmitted through hand which caused foodborne disease (Baser et al., 2016).

In the aspect of cross contamination, majority of the respondents (93.4\%) were aware on the possibility of cross contamination if the same gloves were used to handle both vegetable and meat items, wearing a watch and jewellery during food preparation (82.2\%), and separation of raw foods and cooked foods (90.0\%). Even though the percentage of agree showed the majority, some of the respondents still did not know (17.7\%) that watch and jewellery can also transmit germs on hands and prepared foods. A similar finding by Webb and Morancie (2015) concluded that university food handlers in Trinidad and Tobago wore jewellery during food handling and did not know the negative effect of it.

Regarding time and temperature control, majority of the respondents (95.6\%) showed good knowledge pertaining to the correct range of the temperature for freezer and refrigerator. The food handlers knew that frozen food should be stored in the freezer with the temperature below $-18^{\circ} \mathrm{C}$ while cold food is stored in the refrigerator with the range of temperature of $1^{\circ} \mathrm{C}$ to $4^{\circ} \mathrm{C}$. Then, about $11.1 \%$ of the respondents disagreed on the range temperature of 'danger zone' which was $5^{\circ} \mathrm{C}$ to $63^{\circ} \mathrm{C}$. It is supported by the findings from Nur Izyan et al. (2019) in which half of the respondents from home-based food providers in Klang Valley did not know the food's temperature 'danger zone'. Then, about $87.8 \%$ of the respondents agreed that cooked food should not be kept more than 4 hours at room temperature. According to Dora-Liyana et al. (2019), majority of the food handlers showed the correct response towards advanced food preparation and keeping food less than 4 hours at room temperature. It is further supported by Abdul-Mutalib, Syafinaz, Sakai, and Shirai (2015) who noted that it was a norm for earlier or advanced food preparation practiced by the food service establishment.

Furthermore, food handlers should be aware of the right food holding temperature to minimize bacterial growth. In line with the above statement, majority of the respondents $(96.7 \%) \mathrm{knew}$ that improper holding of food at the right temperature could lead to foodborne illness. Besides, about $17.8 \%$ of the respondents disagreed that hot and ready-to-eat food should be kept at a temperature higher than $63^{\circ} \mathrm{C}$ to avoid the 'danger zone'. According to Annon (as cited in Siow \&Sani, 2011), inappropriate temperatures during food preparation was one of the main contributions to the reports of foodborne disease cases. 
Although more than half of the respondents agreed, about $30.0 \%$ of the respondents disagreed towards the statement that frozen meat items cannot be defrosted by soaking in water. This contributed to the highest percentage of wrong response among all knowledge items. The process of soaking it in water is not a proper technique recommended in food handling as cross contamination could happen when water was in a stagnant state and bacteria may start to spread from raw meat items. The similar findings by Sani and Siow (2014) and Thelwell-Reid (2014) revealed that most of the food handlers gave incorrect response towards the statement related to thawing practices. Besides, the finding from Al-Kandari et al. (2019) concluded that more than half of the respondents knew that thawing frozen food under running water is not the proper way and they prefer to thaw frozen meat in the refrigerator. Therefore, displaying a written manual and graphic that described the proper steps for thawing or defrosting of frozen food was recommended.

Moreover, less than $10 \%$ of the respondents did not recognize some of the bacteria that were associated with foodborne illness cases. However, $91.1 \%$ of the respondents knew that bacteria including Salmonella, Staphylococcus aureus and Shigella can cause foodborne illness towards humans. The finding in this study contradicted with the results obtained by Lee et al. (2017) and Al-Shabib, Mosilhey, and Husain (2016) whereby poor knowledge regarding foodborne pathogens was reported among their respondents. Then, many of the respondents $(86.7 \%)$ knew and believed that all bacteria were not killed during freezing. This is because the bacteria just stopped their growth in that temperature and continued to grow within the temperature of danger zone. The finding from Akabanda et al. (2017) revealed that about $39.2 \%$ of the food handlers in Ghana showed incorrect response as they believed that the freezing process can kill all the bacteria in the food. Next, a satisfactory agree response (93.3\%) was obtained from the respondents towards the statement of broken or cracked dishes could lead to bacterial growth whereby only $6.7 \%$ among them disagreed.

With regards to equipment hygiene, majority of the food handlers (86.7\%) agreed that the use of detergent only was not enough to confirm the efficacy of cleaning equipment. However, $13.3 \%$ of the respondents believed that using the detergent to clean was enough. The extra effort in cleaning equipment was to sanitize it. Moreover, about 93.3\% of the respondents showed the correct response on the statement that cold storages should not be opened frequently for ventilation. Frequently opened cold storages lead to the possibility of the food to be contaminated with possible hazards.

Then, most of the respondents (94.5\%) were confident that hand towels should not be used to wipe the rinsed containers and equipment. This is important as the hand towel of the food handlers might be contaminated with the bacteria from their hands. Therefore, another clean kitchen towel is needed to wipe those containers and equipment by making sure that it is stored in a dry condition. Finally, more than half of the respondents (86.7\%) knew that a separated sink for washing hands and raw materials was an effective way to minimize cross contamination. However, the respondents might not practice it well as limited facilities were provided at the food premises in the campus.

\section{Food Safety Attitude Among on Campus Food Handler}

In the overall results, good response was observed on the attitude measurements. Only $1.1 \%$ to $12.2 \%$ disagreed while most of the respondents $(87.8 \%$ to $98.9 \%)$ agreed with all the true 
statements listed. The results showed that most of the respondents had a positive attitude pertaining to the statement of proper food handling is a vital part of food handler's responsibilities. This result aligned with the results obtained by Tan, Bakar, Karim, Lee and Mahyudin (2013) in which food handlers at primary schools in Hulu Langat showed positive attitudes on the responsibilities of safe food handling. Proper food handling is important when handling food as it may reduce the chances of food being contaminated and eliminate food poisoning outbreak. Then, most of the respondents (97.8\%) agreed that personal cleanliness is important at the workplace. Asmawi et al. (2018) also reported that the same results were obtained from the food handlers at food courts in Petaling Jaya.

Moreover, $96 \%$ of the respondents agreed on the importance of food safety training to reduce the risk of food contamination. Alkandari et al. (2019) also reported that about $78 \%$ of the food handlers in restaurants in Kuwait believed that participation in food safety training would enhance the knowledge on food safety and food handling in daily practice. Food handler or food safety training courses were mentioned earlier on its compulsory requirement for food handler. This training course is important to provide a guideline for food handler on basic food handling and preventing food safety risk. Besides, most of the respondents (95.6\%) also agreed on the importance of separating raw food and cooked food during storage. Cooked food is food that is ready to be served for customers and it must be separated from raw food that might contain any active bacteria which can cause cooked food to be contaminated.

Most of the respondents (96.7\%) were confident on both statements that effective hand cleaning is one of the foodborne disease preventions and the risk of cross contamination can be reduced by using gloves when handling ready-to-eat food. This showed that the respective respondents had a good attitude by ensuring their hands were clean and avoiding direct contact of bare hands-on food prepared. A similar finding by Al-Shabib et al. (2016) noted that almost all food handlers agreed that hands need to be washed prior to handling food.

Although wearing gloves avoids the food handler from having a direct contact with the food, washing hands is still necessary as it is one of the vehicles for the transmission of bacteria such as E. coli spp. (Tan et al., 2013). A previous finding by Lee et al. (2017) also stated that poor hand washing was significant with the result of high bacterial count on food handler's hands. It is worth noting that $91.1 \%$ of the respondents agreed that food handlers who suffered an illness should not be allowed to work on the premises. This is because the sick food handlers might unintentionally transfer germs onto the prepared food or any contact with other things at the food preparation area. Besides, about $94.4 \%$ among food handlers agreed that a proper cooked food is free from contamination. This means that the respondents have a good attitude in making sure that the food is properly prepared to avoid contamination. Furthermore, regarding the attitudes on storage temperature, most of the respondents (97.8\%) strongly agreed that food handlers need to monitor the temperature of the refrigerator and freezer to ensure that the right temperature is set for the food inside and safely stored.

\section{Food Safety Practice Among on Campus Food Handler}

Regarding to the percentage of agreement among respondents, most of the respondents showed good scores on food safety and hygiene practices with the highest amount of percentage $(97.8 \%)$ contributed by the agreed response from the statements of hand washing practices and keeping clean and short fingernails. This result revealed that majority of the 
respondents washed their hands before and after handling food. The comparable results were concluded by Al Suwaidi, Hussein, Al Faisal, El Sawaf, and Wasfy (2015) where most of the food handlers in Dubai had good hand washing practice. Even though from the previous section of attitude question on washing hands prior to wearing glove showed high percentage of disagreement, the practices showed different results.

In fact, most of the respondents (94.4\%) also showed good practice by wearing protective equipment such as cap/head cover, mask, and gloves when handling food. This is one of the ways of preventing any physical, chemical, or biological hazards from contaminating the food. Coughing or sneezing are examples of cross contamination. Also, the female respondents in this study (46.7\%) were all Muslims and wearing head scarves to cover their hair in public may contribute to the high percentage of this practice statement.

Other than that, $10 \%$ of the respondents did wear jewellery while handling food. This practice should be avoided as jewellery can act as a carrier for the transmission of germs towards foods. In this study, $87.8 \%$ respondents agreed that it is a known fact that any food handler is not allowed to work with food if they are suspected or confirmed of having any disease that can be transmitted through food (Codex Alimentarius Commission, 2003). However, it can be said that the food handlers might still come to work due to the shortage of workers on the premises or they are still able to do the job. It is supported by Tan et al. (2013) who revealed that food handler did not take leave because the job can still be done even when they are suffering from an illness. Furthermore, only 3.3\% of the respondents agreed on cleaning work surfaces for all three phases of food handling which included before, during, and after. The cleaning practice at after-phase was aligned with the statement of 'clear and clean as you go' (Food Standard Agency, 2019). There were also the same percentage of agree and disagree for the response of food handlers on the practice of using separate utensil and cutting boards when preparing foods. The result was satisfactory as most of the respondents $(96.7 \%)$ were aware that cross contamination might happen if they used the same knife and cutting board for vegetable and meat items.

Besides, majority of the respondents (91.1\%) agreed on the statement of regularly checking the temperature of chiller or freezer in the premise. However, about $8.9 \%$ disagreed that the temperature of that storage needs to be checked regularly. This finding was aligned with the results obtained by Dora-Liyana et al. (2019) who stated that food handlers at boarding schools in the Northern region of Malaysia checked the temperature of the refrigerator before they store food. Less awareness on the temperature setting might cause the food handler to only realize it after certain changes have happened towards the food stored such as water droplets starting to develop due to temperature rise. Plus, the malfunctioning of the blowers and heating elements of the refrigerator will cause improper food holding (Green \& Selman, 2005).

In this study, only $8.9 \%$ of the respondents believed that food that fell to the floor should not be discarded and can still be used for further processing. However, majority of the respondents (91.1\%) agreed that fallen food might be contaminated and should be discarded. The same finding was reported by Al Suwaidi et al. (2015) whereby majority of the food handlers pick up the fallen food and dispose it. For the statements of keeping food away from the temperature of 'danger zone' and reheating food until steaming hot, the percentage of disagreement showed the highest (13.3\%). This indicated that although majority of the respondents kept 
cooked food below $-18^{\circ} \mathrm{C}$ and hot food above $63^{\circ} \mathrm{C}$ until it was served, there was still a small number of respondents who were not aware of the right holding temperature. Plus, hot cooked food needs to be reheated properly until it is steaming hot before being served to kill the bacteria and avoid bacterial growth. As mentioned by Zanin, Cunha, Rosso, Capriles, and Stedefeldtd (2017), food handlers may perform poor practices pertaining to time and temperature control including cooking and reheating due to the absence or lack of training on food handling.

\section{Relationship between Food Hygiene Knowledge, Attitude and Practices}

All relationships developed was shown in a positive correlation. Plus, all the relationship or the hypothesis developed in this study was accepted as $p$-value was less than 0.01 which indicates significant correlation. In regard with $r$-value, the highest was attitude-practice score $(r=0.586)$ while lowest was knowledge- practice score $(r=0.302)$. Therefore, only the relationship between attitude score and practice score shows moderate positive correlation whereby relationship between knowledge score and attitude score, and knowledge score and practice score show weak positive relationship. In other words, attitude was believed to give higher impact on practice rather than knowledge towards practices. Therefore, the good score in knowledge may not always turn into a good practice (Akabanda et al., 2017).

Table 1: Results for Pearson's Correlation Analysis

\begin{tabular}{|c|c|c|c|c|}
\hline & r-value & Relationship & $\begin{array}{l}\text { Hypothesis } \\
\text { Decision }\end{array}$ & Results \\
\hline $\begin{array}{l}\text { Knowledge Score - } \\
\text { Attitude Score }\end{array}$ & 0.359 & $\begin{array}{l}\text { Weak Positive } \\
\text { Correlation }\end{array}$ & $p=0.001<p=0.01$ & Accepted \\
\hline $\begin{array}{l}\text { Knowledge Score - } \\
\text { Practice Score }\end{array}$ & 0.302 & $\begin{array}{l}\text { Weak Positive } \\
\text { Correlation }\end{array}$ & $p=0.004<p=0.01$ & Accepted \\
\hline $\begin{array}{l}\text { Attitude Score - } \\
\text { Practice Score }\end{array}$ & 0.586 & $\begin{array}{l}\text { Moderate Positive } \\
\text { Correlation }\end{array}$ & $p=0.000<p=0.01$ & Accepted \\
\hline
\end{tabular}

\section{Attitude mediate the relationship between Food Hygiene Knowledge and Practice}

The results of the regression indicated that the knowledge without attitude variable explained only $9.1 \%$ of the variance in practice $\left(R^{2}=0.091, F(1,88)=8.856, p\right.$ - value $\left.=0.004\right)$. However, the value of $R^{2}$ was increased when present of attitude between the relationship and $35.3 \%$ of variance in practice can be predicted by knowledge $\left(R^{2}=0.353, F(2,87)=23.702\right.$, $p$ value $=0.000$ ). Moreover, only $12.9 \%$ of variance in attitude score can be predicted by knowledge score $\left(R^{2}=0.129, F(1,88)=13.009, p\right.$-value $\left.=0.001\right)$ and $34.3 \%$ of variance in practice score can be predicted by attitude score $\left(R^{2}=0.343, F(1,88)=45.928, p\right.$-value $\left.=0.000\right)$. From Anova results, all regression model was significant. From the results, all t-value was more than 2 except for knowledge-practice relationship with the present of attitude. This indicate that knowledge with the present of attitude was not significantly predicted practice. Therefore, attitude mediated the relationship between knowledge and practice of food safety and hygiene. Same finding was concluded by Zanin et al., (2017) and Sayuti et al (2020). 
Table 2: Results for Anova Analysis

\begin{tabular}{lcccc}
\hline Relationship & $\mathbf{R}^{\mathbf{2}}$ & $\begin{array}{c}\text { Sig. (Anova } \\
\text { Results) }\end{array}$ & t-value & $\begin{array}{c}\text { Standardized } \\
\text { coefficient ( } \boldsymbol{\beta} \text { ) }\end{array}$ \\
\hline $\begin{array}{l}\text { Knowledge-Practice } \\
\text { (without Attitude) }\end{array}$ & 0.091 & 0.004 & 2.967 & 0.302 \\
$\begin{array}{l}\text { Knowledge-Practice } \\
\text { (with Attitude) }\end{array}$ & 0.353 & 0.000 & 1.146 & 0.106 \\
$\begin{array}{l}\text { Knowledge- Attitude } \\
\text { Attitude-Practice }\end{array}$ & 0.129 & 0.001 & 3.607 & 0.359 \\
\hline
\end{tabular}

\section{Conclusion}

The knowledge and attitude towards hygiene practices among campus food handlers were assessed. The results showed that most of the respondents had a positive attitude pertaining to the statement that proper food handling is a vital part of food handler's responsibilities. Despite showing good food hygiene knowledge, lacking in food handlers' knowledge in association to time and temperature control as well as cross contamination was encountered. This is very crucial in preventing foodborne illness. The results also revealed that there is significant relationship between food hygiene knowledge and practice and attitude mediated the relationship between them. Hence, it can be suggested that hygiene attitude needs to be developed in the hearts of food handlers particularly during unexpected changes which included Covid-19 pandemic disease.

\section{Acknowledgment}

The authors would like to thank Universiti Teknologi MARA for the facilities and ICARE Management of UiTM Selangor for providing required data during research being conducted.

\section{Corresponding Author}

Norhidayah Abdullah. Faculty of Hotel and Tourism Management, Universiti Teknologi MARA Selangor, Puncak Alam Campus, Selangor.

Email: norhi813@uitm.edu.my

\section{References}

Abdul-Mutalib, N., Syafinaz, A., Sakai, K., \& Shirai, Y. (2015). An overview of foodborne illness and food safety in Malaysia. International Food Research Journal, 22(3), 896-901.

Akabanda, F., Hlortsi, E. H., \& Owusu-Kwarteng, J. (2017). Food Safety Knowledge, Attitudes, and Practices of Institutional Food Handlers in Ghana. BMC Public Health, 17(40), 1-9.

Al Suwaidi, A. H., Hussein, H., Al Faisal, W., El Sawaf, E., \& Wasfy, A. (2015). Hygienic Practices Among Food Handlers in Dubai. International Journal of Preventive Medicine Research, 1(3), 101-108.

Al-Kandari, D., Al-abdeen, J., \& Sidhu, J. (2019). Food safety knowledge, attitudes, and practices of food handlers in restaurants in Kuwait. Food Control (103), 103-110.

Al-Shabib, N. A., Mosilhey, S. H., \& Husain, F. M. (2016). Cross-sectional study on food safety knowledge, attitude and practices of male food handlers employed in restaurants of King Saud University, Saudi Arabia. Food Control, 59, 212-217.

Asmawi, U. M., Norehan, A. A., Salikin, K., Rosdi, N. A., Munir, N. A., Basri, N. B., Nor, N. M. (2018). An Assessment of Knowledge, Attitudes and Practices in Food Safety Among 
Food Handlers Engaged in Food Courts. Current Research in Nutrition and Food Science, 6(2), 346-353.

Baser, F., Ture, H., Abubakirova, A., Sanlier, N., \& Cil, B. (2016). Structural modeling of the relationship among food safety knowledge, attitude and behavior of hotel staff in Turkey. Food Control, 73, 438-444.

Baser, F., Ture, H., Abubakirova, A., Sanlier, N., \& Cil, B. (2017). Structural modeling of the relationship among food safety knowledge, attitude and behavior of hotel staff in Turkey. Food Control, 73, 438-444.

Borgers, N., Sikkel, D., \& Hox, J. (2004). Response Effects in Surveys on Children and Adolescents: The Effect of Number of Response Options, Negative Wording, and Neutral Mid-Point. Quality and Quantity, 38(1), 17-33.

Codex Alimentarius Comission. (2003). Recommended international code of practice general 437 principles of food hygiene (2003) CAC/RCP 1-1969, Rev. 4. World Health Organization.

Department of Statistics Malaysia. (2017). Food and Beverage Services Value Added Recorded Double Digit Growth of 11.2 per cent as compared to 2010. Retrieved from Department of Statistics Malaysia Official Website: https://www.dosm.gov.my

Dora-Liyana, A. L., Mahyudin, N. A., Ismail-Fitry, M. R., Ahmad-Zaki, A., \& Rasiyuddin, H. (2018). Food safety and hygiene knowledge, attitude, and practices among food handlers at boarding schools in the Northern Region of Malaysia. International Journal of Academic Research in Business and Social Sciences, 8(17), 238-266.

Duda-Chodak, A., Lukasiewicz, M., Zie C, G., Florkiewicz, A., \& Filipiak-Florkiewicz, A. (2020). Covid-19 pandemic and food: Present knowledge, risks, consumers fears and safety. Trends in Food Science \& Technology (105), 145-160.

Elengoe, A. (2020). COVID-19 Outbreak in Malaysia. Osong Public Health Res Perspect, 11(3), 93-100.

Food Standards Agency. (2019). Safe Method: Clear and Clean as You Go.

Green, L. R., \& Selman, C. (2005). Factors impacting food workers' and managers' safe food preparation practices: A qualitative study. Food Protection Trends, 25(12), 981-990.

Jurnalis Shah Alam. (2019). Aduan Pelajar. Retrieved from Jurnalis Shah Alam: http://jurnalisshahalam.blogspot.com/p/aduan-pelajar.html

Kubde, S. R., Pattankar, J., \& Kokiwar, P. R. (2016). Knowledge and food hygiene practices among food handlers in food establishments. International Journal of Community Medicine and Public Health, 3(1), 251-256.

Kunadu, A.-H., Ofosu, D. B., Aboagye, E., \& Tano-Debrah, K. (2016). Food safety knowledge, attitudes, and self-reported practices of food handlers in institutional foodservice in Accra, Ghana. Food Control, 69, 324-330.

Lee, H. K., Halim, H. A., Thong, K. L., \& Chai, L. C. (2017). Assessment of Food Safety Knowledge, Attitude, Self-Reported Practices, and Microbiological Hand Hygiene of Food Handlers. International Journal of Environmental Research and Public Health, 14(55), 1-14.

Liyana, I. (2020). Viral masak lemang di dalam tin, KKM tegaskan TIDAK SELAMAT! Sinar Harian. Retrieved from https://m.sinarharian.com.my/mobile-article?articleid=106668

Izyan, N. F., Zuraini, M., Maria, M., Lovelyna, B., Maimunah, M., \& Saidatul Afzan, A. (2019). A Preliminary Study on Food Safety Knowledge, Attitude and Practices Among HomeBased Food Providers In Klang Valley, Malaysia. Malaysian Applied Biology, 48(2), 157160. 
Sani, N. A., \& Siow, O. N. (2014). Knowledge, attitudes, and practices of food handlers on food safety in food service operations at the Universiti Kebangsaan Malaysia. Food Control, 37(1), 210-217.

Sayuti, Y. A., Albattat, A., Ariffina, A. Z., Nazrina, N. S., \& Silahudeen, T. N. (2020). Food safety knowledge, attitude and practices among management and science university students, Shah Alam. Management Science Letters, 10, 929-936.

Siow, O. N., \& Sani, N. A. (2011). Assessment of Knowledge, Attitudes and Practices (KAP) Among Food Handlers at Residential Colleges and Canteen Regarding Food Safety. Sains Malaysiana, 40(4), 403-410.

Soon, J., Singh, H., \& Baines, R. (2011). Foodborne diseases in Malaysia: A review. Food Control, 22, 823-830.

Tan, S. L., Bakar, F. A., Karim, M. S., Lee, H. Y., \& Mahyudin, N. A. (2013). Hand hygiene knowledge, attitudes, and practices among food handlers at primary schools in Hulu Langat district, Selangor (Malaysia). Food Control, 34, 428-435.

Thelwell-Reid, M. A. (2014). Food Safety Knowledge and Self-Reported Practices of Food Handlers in Jamaica. Walden Dissertations and Doctoral Studies, 1-205.

Webb, M., \& Morancie, A. (2015). Food safety knowledge of foodservice workers at a university campus by education level, experience, and food safety training. Food Control, $50,259-264$.

Yahaya, N. (2018). Recent Development of International Higher Education in Malaysia. Singapore: Asia-Pacific Association for International Education.

Zanin, L. M., Cunha, D. T., Rosso, V. V., Capriles, V. D., \& Stedefeldtd, E. (2017). Knowledge, attitudes, and practices of food handlers in food safety: An integrative review. Food Research International, 100, 53-62. 